\title{
The 2004 Indian tsunami in Thailand: Surveyed runup heights and tide gauge records
}

\author{
Yoshinobu Tsuji ${ }^{1}$, Yuichi Namegaya ${ }^{1}$, Hiroyuki Matsumoto ${ }^{2}$, Sin-Iti Iwasaki ${ }^{3}$, Wattana Kanbua ${ }^{4}$, \\ Mongkonkorn Sriwichai ${ }^{5}$, and Vorawit Meesuk ${ }^{6}$ \\ ${ }^{1}$ Eearthquake Research Institute, University of Tokyo, 1-1-1 Yayoi, Bunkyo-ku, Tokyo 113-0032, Japan \\ ${ }^{2}$ Japan Agency for Marine-Earth Science and Technology, 2-15, Natsushima, Yokosuka 237-0061, Japan \\ ${ }^{3}$ National Research Institute for Earth Science and Disaster Prevention, 3-1 Tennodai, Tsukuba 305-0006, Japan \\ ${ }^{4}$ Thai Meteorological Department, Sukhumvit Rd., Bangna, Bangkok 10260, Thailand \\ ${ }^{5}$ Rangsit University, Phaholyothin Rd. Lak-Hok, Pathumhani 12000, Thailand \\ ${ }^{6}$ Hydro and Agro Informatics Institute, Rangnam Rd., Phayathai, Ratchatewi, Bangkok 10400, Thailand
}

(Received June 30, 2005; Revised September 5, 2005; Accepted September 23, 2005; Online published February 17, 2006)

\begin{abstract}
Tsunami accompanied with the Sumatra earthquake of 26 December 2004 affected many countries around the Indian Ocean. Thailand located approximately $500 \mathrm{~km}$ east of its source, was also severely suffered from the tsunami. From 24 February through 4 March 2005, we surveyed the damaged areas in Thailand from south of Phuket Island up to the border of Myanmar including four islands. The whole coastal area facing the Andaman Sea could be covered. We measured 37 points in total, the tsunami heights are less than $10 \mathrm{~m}$, except at a few locations. We found that the largest tsunami height reached up to $19.6 \mathrm{~m}$ at Ban Thung Dap of Phra Thong Island. During our survey, we also collected five paper copies of analog tide gauge records. In addition that we could detect two other tide gauge records from the web-site. Therefore, totally seven tide gauge records were obtained in Thailand. All of the recorded tsunami waveforms indicate that sea level initially withdrew with duration in 30 to $60 \mathrm{~min}$, followed by the rising-up. This phenomenon corresponds to the eyewitnesses' accounts of the survivors who experienced the tsunami.
\end{abstract}

Key words: The 2004 Sumatra earthquake, tsunami, field survey, Thailand, tide gauge record.

\section{Introduction}

On 26 December 2004 at 00:58:53 UTC (07:58 in Thai local time), a megathrust earthquake occurred west off the north part of Sumatra Island, Indonesia with its moment magnitude of 9.0 (USGS, 2005), which is the fourth largest among the instrumentally recorded earthquakes. Tsunami accompanied with the earthquake propagated across the Indian Ocean and caused the catastrophic disasters in many countries facing the Indian Ocean. The countries which suffered the most number of casualties due to the tsunami are Indonesia ( $>160,000$ casualties), Sri Lanka $(35,000)$, India $(16,000)$ and Thailand $(8,300)$. Post field surveys to measure the tsunami heights and to investigate damages caused by the tsunami have been carried out by some international teams, whose results and summaries are complied at http://www.drs.dpri.kyoto-u.ac.jp/sumatra/index-e.html.

Four days after the event, Matsutomi et al. (2005) visited Thailand that is located approximately $500 \mathrm{~km}$ east from the tsunami source for one week as the first international survey team. Satake et al. (2005) then followed from 28 to 29 , January 2005 . According to their preliminary results, the tsunami heights were measured to be more than $5 \mathrm{~m}$ in Phuket Island, and more than $10 \mathrm{~m}$ in Khao Lak located about $50 \mathrm{~km}$ north of Phuket Island. Two previ-

Copyright (c) The Society of Geomagnetism and Earth, Planetary and Space Sciences (SGEPSS); The Seismological Society of Japan; The Volcanological Society of Japan; The Geodetic Society of Japan; The Japanese Society for Planetary Sciences; TERRAPUB. ous surveys were almost finished in Phuket Island and Khao Lak. From 24 February through 4 March 2005, we surveyed along the coastal area between Phuket Island and Ranong, so that the whole area along the Andaman Sea would be covered. Tsunami height survey on the coast as far north as the border of Thailand, i.e., Myanmar coast, was carried out by Satake et al. (2006). The preliminary report of our survey has been published by Namegaya et al. (2005) in Japanese.

Eight tide gauge stations exist on the coast of the Andaman Sea in Thailand, which are operated by two different organizations; five of them are operated by Thai Marine Department (TMD) and three of them are operated by Hydrographic Department of Royal Thai Navy (HDRTN). Seven stations were in operation and recorded the whole sea level change during the tsunami attacks. We visited some of the tide stations, and collected information on their structure and accuracy, in addition to the recorded tsunami waveforms.

In this paper, the measurements of tsunami heights as well as the tide gauge data of the 2004 Indian tsunami on the Andaman Sea coast of Thailand are reported.

\section{Summary of the Survey}

We organized a combined survey team of 6 scientists both from Japan and Thailand, of which Tsuji served as a leader. Iwasaki visited Thailand and negotiated both with Thai Meteorological Department and Hydrographic Department of 


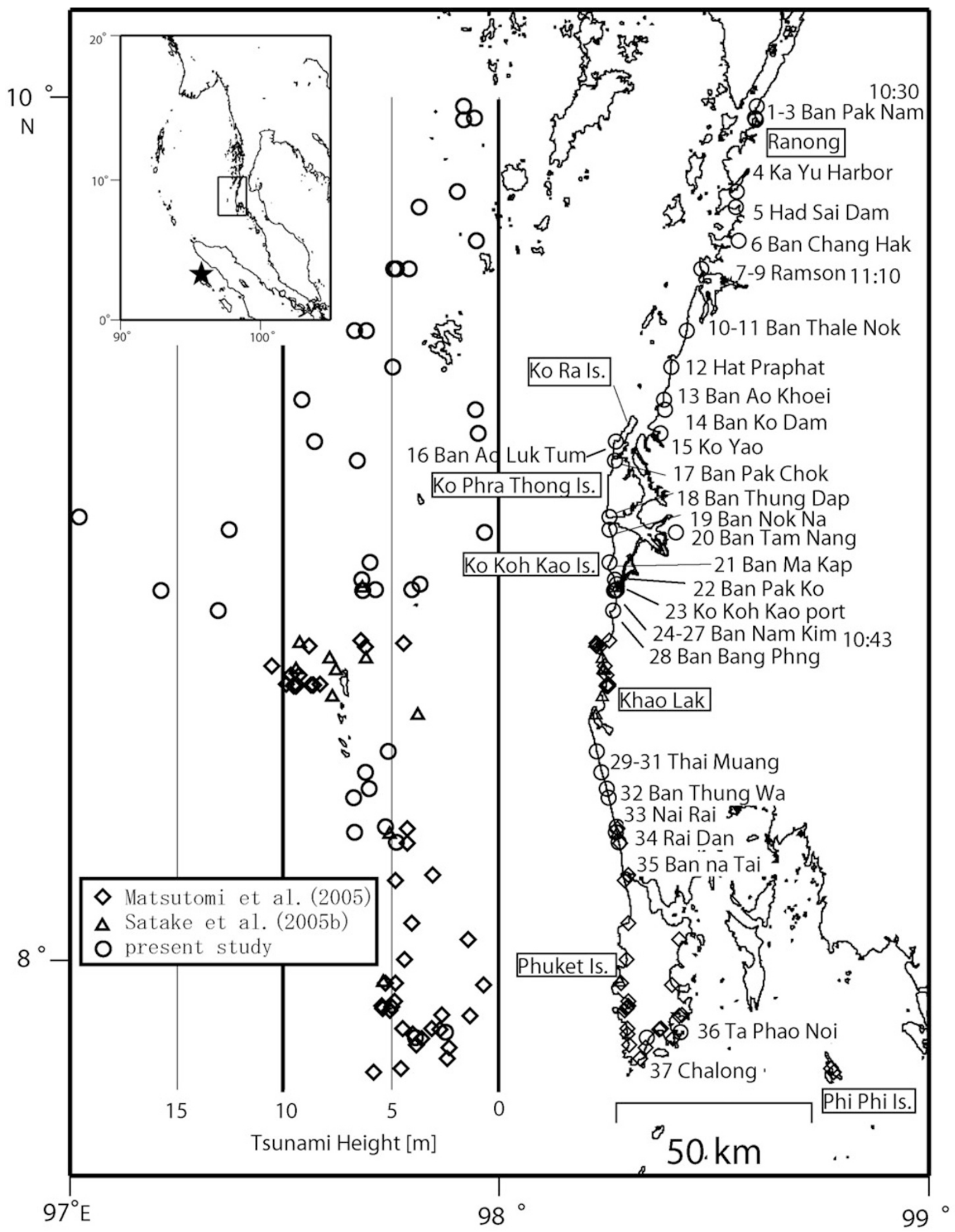

Fig. 1. Tsunami heights measured on the Andaman Sea coast of Thailand.

Royal Thai Navy prior to our field survey. After Iwasaki came back to Japan, he maintained daily communication with our team during the survey.

We arrived in Thailand on 24 February 2005, and we had a pre-survey meeting to discuss the plans and objectives of the survey at Hydro and Agro Informatics Institute (HAII) in Bangkok at first. We then moved to Phuket Island and we started to survey as far north as Ranong until 3 March 2005. We proceeded northward along the coast of the Andaman Sea, while we decided where we would survey for the next 
Table 1. Tsunami height measured by the present team. As for the meanings of distance, $H, T, D, W, B$, and $R$ in type column, see the text. Reliability is based on the guideline of IUGG Tsunami Commission.

\begin{tabular}{|c|c|c|c|c|c|c|c|c|c|}
\hline \multirow{2}{*}{$\begin{array}{r}\text { No. } \\
1\end{array}$} & \multirow{2}{*}{$\begin{array}{l}\text { Measured Point } \\
\text { Ban Pak Nam port }\end{array}$} & \multicolumn{2}{|c|}{ Longitude } & \multicolumn{2}{|c|}{ Latitude } & \multirow{2}{*}{$\begin{array}{c}\begin{array}{c}\text { Distance } \\
(\mathrm{m})\end{array} \\
0\end{array}$} & \multirow{2}{*}{$\begin{array}{c}\text { Tsunami Height } \\
(\mathrm{m}) \\
1.7\end{array}$} & \multirow{2}{*}{$\begin{array}{c}\text { Reliability } \\
\text { A }\end{array}$} & \multirow{2}{*}{$\begin{array}{c}\text { Type } \\
\mathrm{H}\end{array}$} \\
\hline & & $98^{\circ}$ & $36.035^{\prime}$ & $9^{\circ}$ & $58.743^{\prime}$ & & & & \\
\hline 2 & Ban Pak Nam & $98^{\circ}$ & $35.744^{\prime}$ & $9^{\circ}$ & $57.044^{\prime}$ & 0 & 1.2 & A & $\mathrm{H}$ \\
\hline 3 & Ban Pak Nam fishering port & $98^{\circ}$ & $35.877^{\prime}$ & $9^{\circ}$ & $56.764^{\prime}$ & 0 & 1.7 & A & $\mathrm{H}$ \\
\hline 4 & Ka Yu Harbor & $98^{\circ}$ & $33.225^{\prime}$ & $9^{\circ}$ & $46.876^{\prime}$ & 0 & 2.0 & A & $\mathrm{H}$ \\
\hline 5 & Had Sai Dam & $98^{\circ}$ & $33.137^{\prime}$ & $9^{\circ}$ & $44.663^{\prime}$ & 105 & 3.7 & $\mathrm{~B}$ & $\mathrm{~T}$ \\
\hline 6 & Ban Chang Hak & $98^{\circ}$ & $33.514^{\prime}$ & $9^{\circ}$ & $40.113^{\prime}$ & 0 & 1.1 & A & $\mathrm{H}$ \\
\hline 7 & Ramson & $98^{\circ}$ & $28.217^{\prime}$ & $9^{\circ}$ & $36.130^{\prime}$ & 329 & 4.8 & A & $\mathrm{H}, \mathrm{W}$ \\
\hline 8 & Ramson & $98^{\circ}$ & $28.217^{\prime}$ & $9^{\circ}$ & $36.130^{\prime}$ & 329 & 4.9 & A & $\mathrm{B}$ \\
\hline 9 & Ramson & $98^{\circ}$ & $28.217^{\prime}$ & $9^{\circ}$ & $36.130^{\prime}$ & 329 & 4.2 & A & $\mathrm{H}, \mathrm{W}$ \\
\hline 10 & Ban Thale Nok & $98^{\circ}$ & $26.236^{\prime}$ & $9^{\circ}$ & $27.589^{\prime}$ & 121 & 6.8 & A & $\mathrm{B}$ \\
\hline 11 & Ban Thale Nok & $98^{\circ}$ & $26.236^{\prime}$ & $9^{\circ}$ & $27.589^{\prime}$ & 121 & 6.2 & A & $\mathrm{W}$ \\
\hline 12 & Hat Praphat & $98^{\circ}$ & $24.041^{\prime}$ & $9^{\circ}$ & $22.571^{\prime}$ & 939 & 5.0 & A & $\mathrm{H}, \mathrm{W}$ \\
\hline 13 & Ban Ao Khoei & $98^{\circ}$ & $23.020^{\prime}$ & $9^{\circ}$ & $17.955^{\prime}$ & 180 & 9.2 & $\mathrm{C}$ & $\mathrm{T}$ \\
\hline 14 & Ban Ko Dam & $98^{\circ}$ & $23.147^{\prime}$ & $9^{\circ}$ & $16.636^{\prime}$ & 0 & 1.1 & A & $\mathrm{H}$ \\
\hline 15 & Ko Yao, fishing village & $98^{\circ}$ & $22.496^{\prime}$ & $9^{\circ}$ & $13.324^{\prime}$ & 0 & 1.0 & A & $\mathrm{H}$ \\
\hline 16 & Ban Ao Luk Tum & $98^{\circ}$ & $16.333^{\prime}$ & $9^{\circ}$ & $12.169^{\prime}$ & 74 & 8.6 & A & $\mathrm{R}$ \\
\hline 17 & Ban Pak Chok & $98^{\circ}$ & $16.258^{\prime}$ & $9^{\circ}$ & $9.586^{\prime}$ & 236 & 6.6 & $\mathrm{~B}$ & $\mathrm{~W}, \mathrm{~T}$ \\
\hline 18 & Ban Thung Dap & $98^{\circ}$ & $15.424^{\prime}$ & $9^{\circ}$ & $1.702^{\prime}$ & 30 & 19.6 & B & $\mathrm{T}$ \\
\hline 19 & Ban Nok Na & $98^{\circ}$ & $15.391^{\prime}$ & $8^{\circ}$ & $59.941^{\prime}$ & 136 & 12.6 & $\mathrm{~B}$ & $\mathrm{H}, \mathrm{T}$ \\
\hline 20 & Ban Tam Nang & $98^{\circ}$ & $24.718^{\prime}$ & $8^{\circ}$ & $59.575^{\prime}$ & 0 & 0.7 & $\mathrm{C}$ & $\mathrm{H}$ \\
\hline 21 & Ban Ma Kap & $98^{\circ}$ & $15.489^{\prime}$ & $8^{\circ}$ & $55.365^{\prime}$ & 148 & 6.0 & A & $\mathrm{B}$ \\
\hline 22 & Ban Pak Ko & $98^{\circ}$ & $16.206^{\prime}$ & $8^{\circ}$ & $52.945^{\prime}$ & 263 & 6.4 & A & $\mathrm{B}$ \\
\hline 23 & Ko Koh Kao port & $98^{\circ}$ & $16.517^{\prime}$ & $8^{\circ}$ & $52.315^{\prime}$ & 43 & 3.7 & A & $\mathrm{H}$ \\
\hline 24 & Ban Nam Kim & $98^{\circ}$ & $16.501^{\prime}$ & $8^{\circ}$ & $51.590^{\prime}$ & 0 & 4.1 & A & $\mathrm{W}$ \\
\hline 25 & Ban Nam Kim & $98^{\circ}$ & $16.347^{\prime}$ & $8^{\circ}$ & $51.159^{\prime}$ & 133 & 5.8 & A & W \\
\hline 26 & Ban Nam Kim & $98^{\circ}$ & $16.340^{\prime}$ & $8^{\circ}$ & $51.530^{\prime}$ & 25 & 6.4 & A & $\mathrm{W}$ \\
\hline 27 & Ban Nam Kim & $98^{\circ}$ & $16.090^{\prime}$ & $8^{\circ}$ & $51.433^{\prime}$ & 63 & 15.8 & $\mathrm{~B}$ & $\mathrm{~T}$ \\
\hline 28 & Ban Bang Phng & $98^{\circ}$ & $15.963^{\prime}$ & $8^{\circ}$ & $48.748^{\prime}$ & 9 & 13.1 & $\mathrm{~B}$ & $\mathrm{~T}$ \\
\hline 29 & $\begin{array}{l}\text { Thai Muang, Natural } \\
\text { Conservation Park }\end{array}$ & $98^{\circ}$ & $13.651^{\prime}$ & $8^{\circ}$ & $29.065^{\prime}$ & 462 & 5.2 & A & $\mathrm{H}, \mathrm{T}$ \\
\hline 30 & Thai Muang, visitor center & $98^{\circ}$ & $14.303^{\prime}$ & $8^{\circ}$ & $26.150^{\prime}$ & 463 & 6.3 & $\mathrm{~A}$ & $\mathrm{H}, \mathrm{W}$ \\
\hline 31 & Thai Muang & $98^{\circ}$ & $15.017^{\prime}$ & $8^{\circ}$ & $23.913^{\prime}$ & 114 & 6.1 & A & $\mathrm{H}$ \\
\hline 32 & Ban Thung Wa & $98^{\circ}$ & $15.315^{\prime}$ & $8^{\circ}$ & $22.663^{\prime}$ & 444 & 6.8 & $\mathrm{C}$ & $\mathrm{T}$ \\
\hline 33 & Nai Rai & $98^{\circ}$ & $16.395^{\prime}$ & $8^{\circ}$ & $18.585^{\prime}$ & 534 & 5.3 & A & $\mathrm{H}, \mathrm{W}$ \\
\hline 34 & Rai Dan & $98^{\circ}$ & $16.301^{\prime}$ & $8^{\circ}$ & $17.817^{\prime}$ & 41 & 6.8 & $\mathrm{~B}$ & H, D \\
\hline 35 & Ban Na Tai & $98^{\circ}$ & $16.666^{\prime}$ & $8^{\circ}$ & $16.442^{\prime}$ & - & 4.8 & A & $\mathrm{R}$ \\
\hline 36 & Ta Phao Noi & $98^{\circ}$ & $25.342^{\prime}$ & $7^{\circ}$ & $50.032^{\prime}$ & - & 2.6 & A & $\mathrm{H}$ \\
\hline 37 & Chalong & $98^{\circ}$ & $20.682^{\prime}$ & $7^{\circ}$ & $49.262^{\prime}$ & - & 4.0 & A & $\mathrm{W}$ \\
\hline
\end{tabular}

day at every night. After we finished the survey, we came back to Bangkok again, and we presented our preliminary results at Thai Meteorological Department.

Because we could obtain Thai maps on a scale of 1:250000 in Japan, we could have some information such as distribution of major villages on the coast of the Andaman Sea between Phuket Island and Ranong before the survey.
Most villages are located along the national road of Route 4 that runs parallel to the coast line, while some of them are located far from the main road. In the case that our interested spot was inaccessible by a car, we were obliged to approach on foot.

Some offshore islands, such as Ko Ra, Ko Phra Thong Islands that are inaccessible directly by a car exist in the 
(a)

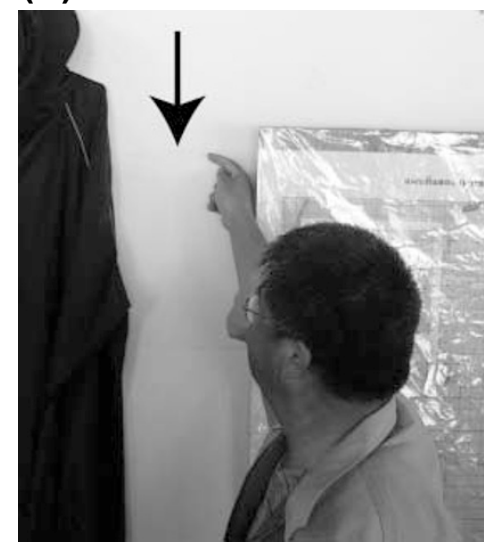

(b)

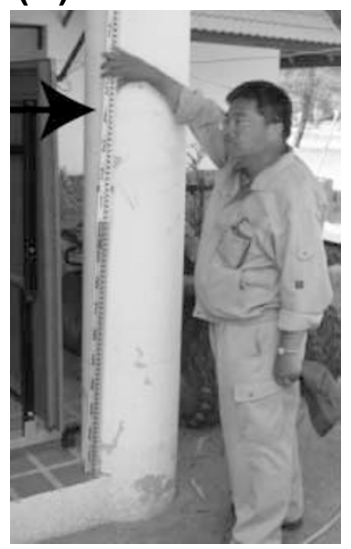

Photo 1. (a) Water mark on the wall, and (b) that on the column at the office of Ramason National Park. (a)

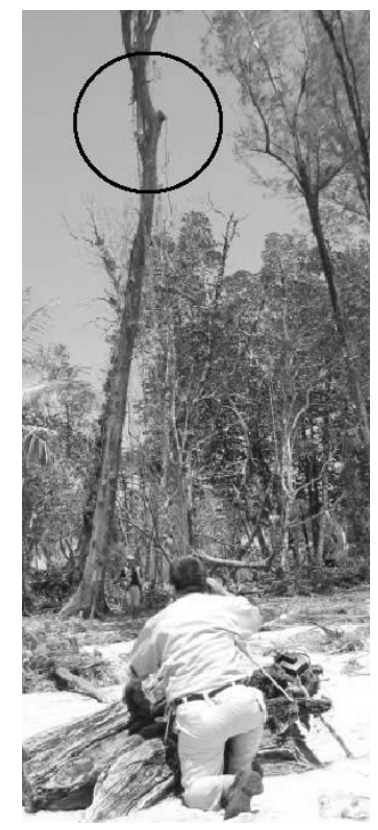

(b)

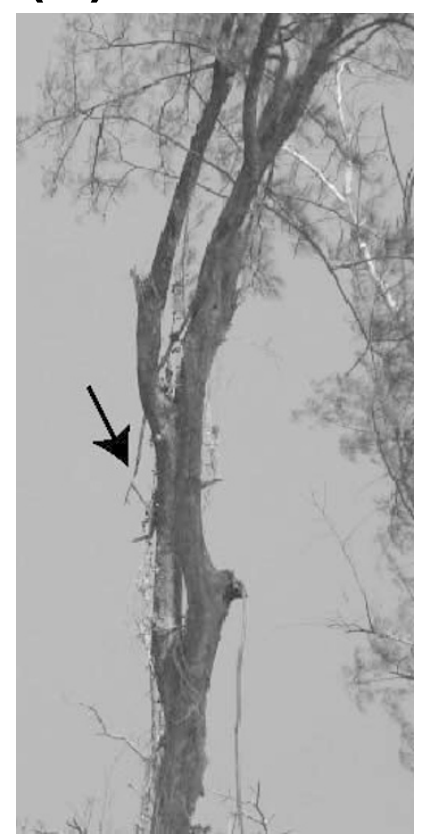

Photo 2. (a) Broken branches due to the tsunami current at Ban Tung Dap, and (b) zoomed up of the circle.

midway between Phuket Island and Ranong. We considered that these islands were severely attacked by the large tsunami, because they are openly faced to the Andaman Sea. We recognized that it was worthwhile to measure the tsunami heights on these islands. Either ferry or chartered boats were used in order to land the islands across the sea.

We surveyed totally 37 points between the southern most poin of Phuket Island and the north of border of Myanmar except for Phuket Island and Khao Lak where two teams had already surveyed. As a result, the whole coastal area of the Andaman Sea in Thailand, including four islands, Ta Phao Noi, Ko Kho Khao, Ko Phra Thong, and Ko Ra Islands could be covered. Measurements of the tsunami height at Chalong in Phuket by Matsutomi et al. (2005) and that at Ban Nam Kim by Satake et al. (2005) are overlapped with

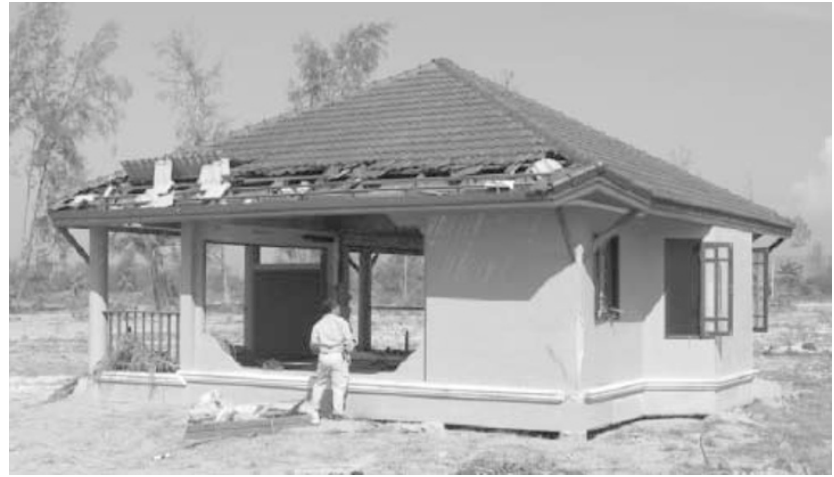

Photo 3. Damaged house by the tsunami at Ban Ma Kap.

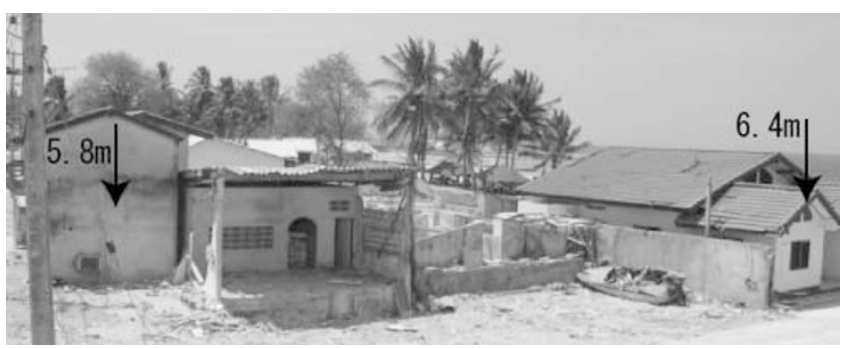

Photo 4. Tsunami height at Ban Nam Kim.

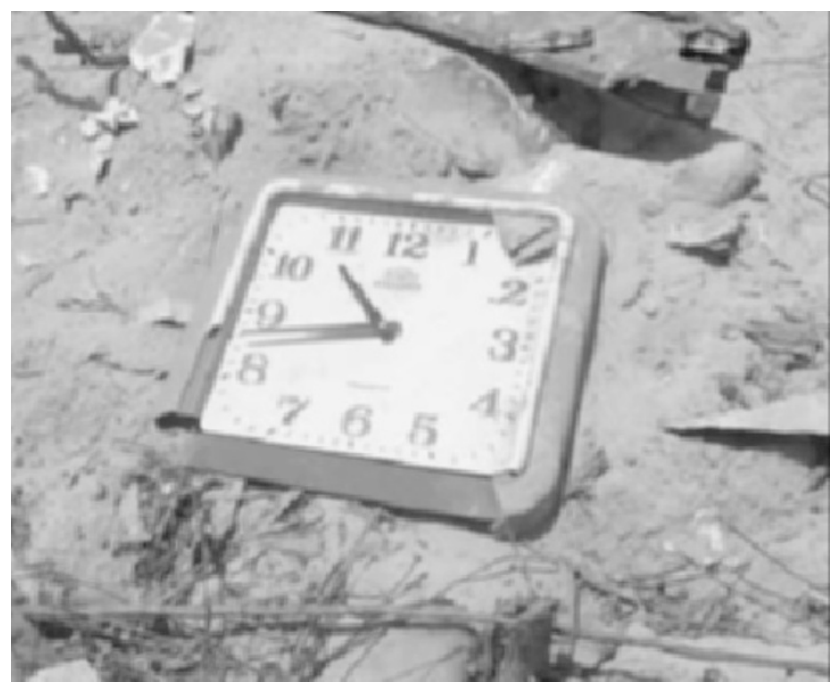

Photo 5. Broken clock at Ban Nam Kim.

ours.

\section{Measurement of Tsunami Height}

For the measurement of tsunami height, six kinds of evidences have been defined and classified as follows, (1) eyewitness accounts by the survivors (denoted by $H$ ), (2) either broken branches on trees or debris on trees or buildings (denoted by $T$ ), (3) death of vegetations due to salty water (denoted by $D$ ), (4) visible water marks on walls or structures (denoted by $W$ ), (5) damaged windows or roofs by water current (denoted by $B$ ), and (6) objectives or vegetations originated in the sea left on beaches, farms, or fields (denoted by $R$ ). Most of inundation or run-up heights could be classified into these six categories above men- 


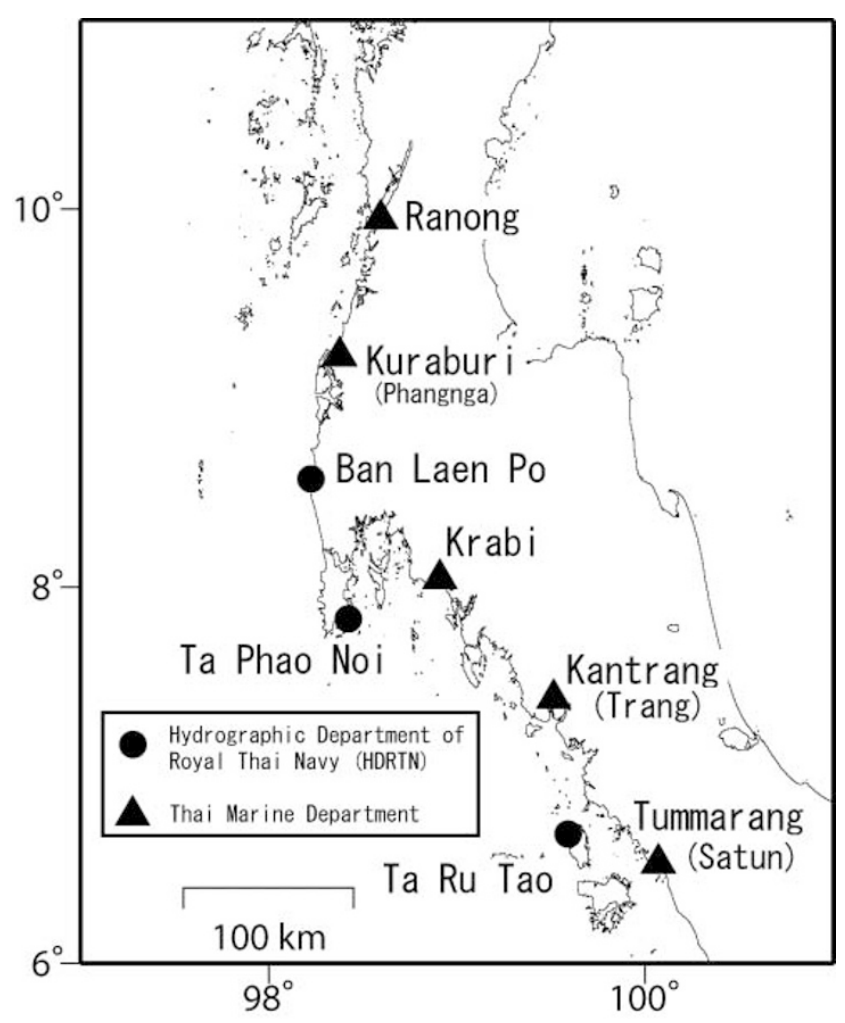

Fig. 2. Location of tide gauge stations in Thailand.

tioned. Based on these categories, we first classified the type of evidences either inundation or run-up, and we then measured its height.

We measured both the vertical and the horizontal penetrations from the shoreline by using both the hand level with the staff and the total station system instrument. We need to compensate the astronomical tidal correction, because the measured heights are based on the local tide level (shoreline level) at the time of each measurement. Difference of elevation between the astronomical tidal levels at the time of tsunami attacks and that of the measurement needs to be compensated to the measured level in order to derive the net tsunami height. Detailed scheme of this compensation is described in the guideline of Intergovernmental Oceanographic Commission (1998). Because Hydrographic Department of Royal Thai Navy and Tsuji et al. (2005) made a chart datum of predicted tidal level, we used these dataset to synchronize the local tidal level. Although other possible meteorological effects such as air pressure or wind surge may be considered, these are not taken into account in the present compensation.

\section{Results of Tsunami Survey}

The results of tsunami height measurements on the coast of the Andaman Sea in Thailand are compiled in Fig. 1 and Table 1, in which location, latitude and longitude at the measured site, horizontal distance from the shoreline, tsunami height after the tide correction, and type of the evidence are presented. Remarks denoting by $H, T, D$, $W, B$ and $R$ indicate the types of evidences mentioned in the previous section. The horizontal distances are calculated from two locations measured by GPS instruments at (a)

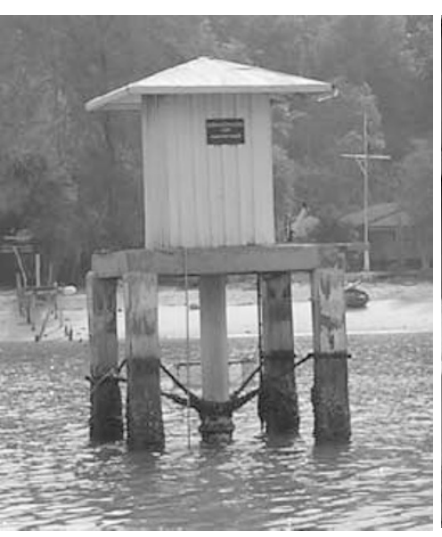

(b)

Photo 6. (a) Tide gauge station at Ta Phao Noi, and (b) the recording equipment.

the penetration limit and at the shoreline as a reference site. Note that the vector connecting between measured and referenced sites are not always at right angle with the shoreline.

Figure 1 in which $\bigcirc, \diamond$, and $\triangle$ indicate tsunami heights measured by our team, Matsutomi et al. (2005), and Satake et al. (2005), respectively, shows the distribution of the tsunami heights. Times shown in Fig. 1 at Ban Pak Nam, Ramson, and Ban Nam Kim represent the tsunami arrival time by eyewitnesses' accounts in local time. We describe the damages due to the tsunami and the condition of some major survey sites from north to south.

4.1 Ban Pak Nam Port (No. 1, indicated number corresponds to that in Fig. 1 and Table 1)

Ban Pak Nam Port at Ranong is located at the border between Thailand and Myanmar, which is the ferryboat terminal connecting to Myanmar. A man who works at the port office said that the sea surface retreated gently and dried up, and the bottom could be seen once, then the sea surface again rose up. Tsunami height of $1.7 \mathrm{~m}$ after the tide correction was measured at a point of inundation on a slope which is pointed by him. We also obtained the other eyewitness account that the sea level change began at about 10:30 in local time.

\subsection{Ramson (Nos. 7, 8, and 9)}

There is an office of the national park in Ramson. Three measurements of tsunami height have been carried out here. The roof of the office has been damaged due to the tsunami, whose height is measured to be $4.9 \mathrm{~m}$. Water mark on the wall inside the office house could be found as shown in Photo 1(a). We measured that the tsunami height on the wall inside the house was $4.8 \mathrm{~m}$. On the other hand, another water mark on the column outside left as shown in Photo 1(b), which is measured to be $4.2 \mathrm{~m}$. The horizontal distance between these two water marks is about $5 \mathrm{~m}$. Even though a horizontal distance between two points is only $5 \mathrm{~m}, 0.6 \mathrm{~m}$ difference of the tsunami height could be found. Assuming that two water marks were made by the same phase of the tsunami current as well as the current speed inside the house was zero, the Bernoulli (or the Torricelli) theorem can be applicable to estimate its current speed. It is 
Table 2. Properties of each tide station, in which $H$ and $D$ represent water depth at the tsunami arrival and diameter of the well, respectively.

\begin{tabular}{llrrrrc}
\hline Station & \multicolumn{2}{c}{ Longitude } & \multicolumn{2}{c}{ Latitude } & H $(\mathrm{m})$ & $\mathrm{D}(\mathrm{cm})$ \\
\hline Ta Phao Noi & $98^{\circ}$ & $25.274^{\prime}$ & $7^{\circ}$ & $50.029^{\prime}$ & 4.70 & 30 \\
Ban Laem Po & $98^{\circ}$ & $13.491^{\prime}$ & $8^{\circ}$ & $34.407^{\prime}$ & - & - \\
Kuraburi & $98^{\circ}$ & $22.613^{\prime}$ & $9^{\circ}$ & $13.503^{\prime}$ & 2.43 & 23 \\
Ban Pak Nam & $98^{\circ}$ & $35.744^{\prime}$ & $9^{\circ}$ & $57.044^{\prime}$ & 2.86 & 17 \\
\hline
\end{tabular}

\section{(a) Kuraburi}

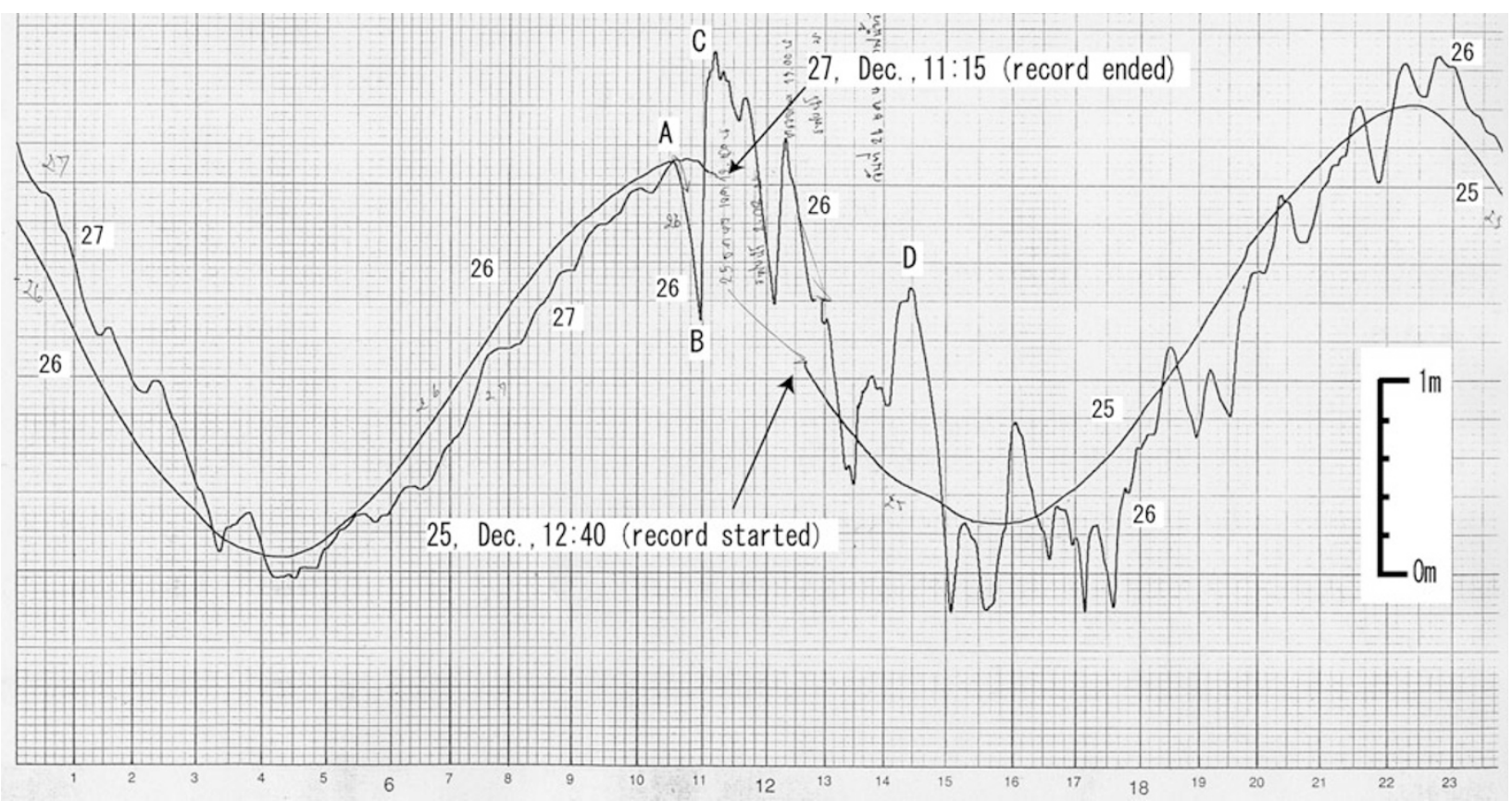

Fig. 3. Tide gauge records at (a) Kuraburi, (b) Tummakarg (Satun), (c) Kan Trang, (d) Krabi, and (e) Ranong.

estimated as $(2 g d)^{1 / 2}$, where $g$ and $d$ is gravity acceleration and difference of water heights, respectively. The current speed could be estimated to be roughly $3.4 \mathrm{~m} / \mathrm{s}$. Because inundation depth is about $1.5 \mathrm{~m}$ as referred to a human's height at the present site as shown in Photo 1(b), the Froude number, which means a ratio of current speed to $(g h)^{1 / 2}$, where $h$ is inundation depth, results in 0.9 , which means the current was subcritical but close to the critical limit. We could obtain the eyewitness account that the arrival time of tsunami was at about 11:10 in local time.

\subsection{Ban Thale Nok (Nos. 10 and 11)}

Only a two-story hospital built by reinforced concrete remained, in contrast that all buildings and houses were completely washed away by the tsunami in Ban Thale Nok. Because the roof of the hospital was damaged by the tsunami, the tsunami height of $6.8 \mathrm{~m}$ could be measured. Visible water mark left on the wall of the second floor inside the hospital, which indicated $6.2 \mathrm{~m}$ high. From the difference between two heights, water current speed could be estimated at $3.4 \mathrm{~m} / \mathrm{s}$, and the Froude number is 0.6 , because of the inundation depth of $3 \mathrm{~m}$.

\subsection{Hat Praphat (No. 12)}

Hat Praphat is where Ranong Coastal Resources Research Station has been established. The tsunami height of $5.0 \mathrm{~m}$ was measured based on the eyewitness account by the staff who said the sea water reached at the lower edge of roof on the first floor. He was carried by the strong current of the tsunami when he was driving a car. After the car was rotated several times, he escaped from the car and climbed up a mangrove tree. Finally, he successfully survived from the tsunami.

\subsection{Ban Thung Dap (No. 18)}

We visited Ban Thung Dap that is located on the southwest of tip of Ko Phra Thong Island. The tsunami height of $19.6 \mathrm{~m}$ was found, which is the highest record of our survey on the Thailand coast. This height was measured by the broken branch of a tree due to the tsunami current (Photo 2). This is not a single evidence, but we could also find several evidences at the same level on other trees here.

\subsection{Ban Ma Kap (No. 21)}

Ban Ma Kap is located at the south of Ko Koh Kao Island, and the ferryboat from Ban Nam Kim is served every hour. Both walls and a roof of an one-story house were broken as shown in Photo 3. The tsunami height was estimated to be 


\section{(b) Tummakarg (Satun)}
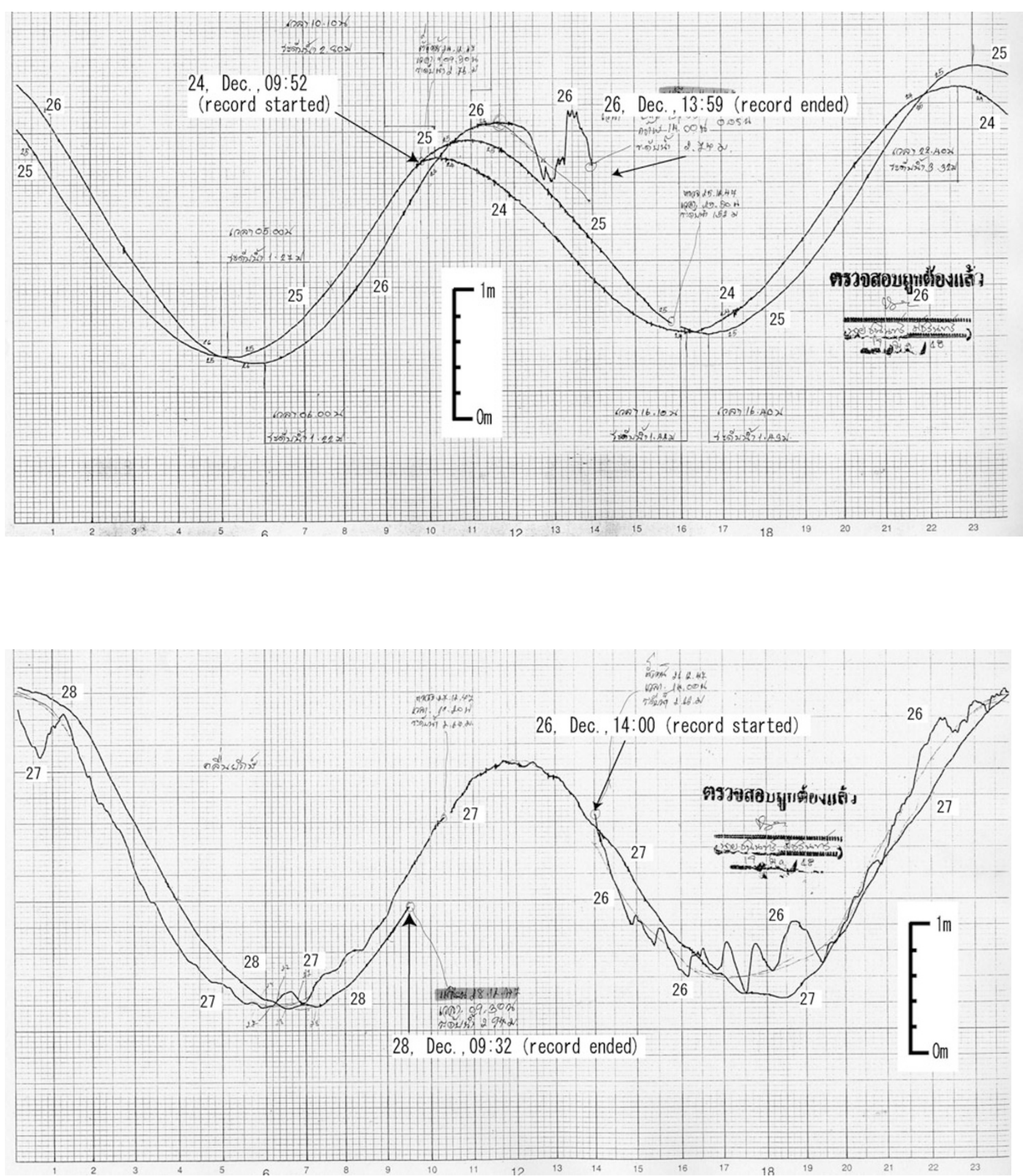

Fig. 3. (continued).

$6.0 \mathrm{~m}$. We considered that the sea water reached at least the damaged upper most tile of the roof. The population of Ko Koh Kao Island was about 800 before the tsunami. About 400 people were killed due to the tsunami, while most of those causalities were not residents but temporal workers from out of the island.

\subsection{Ban Nam Kim (Nos. 25 and 26)}

We could measure two tsunami heights that are close to each other as shown in Photo 4, and both of them were based on the water marks of $5.8 \mathrm{~m}$ and $6.4 \mathrm{~m}$ left on the walls. The distance between two water marks of about 50 $\mathrm{m}$ was too far to derive the current speed. This is why the effects of the dissipation are not negligible and the 


\section{(c) Kan Trang}

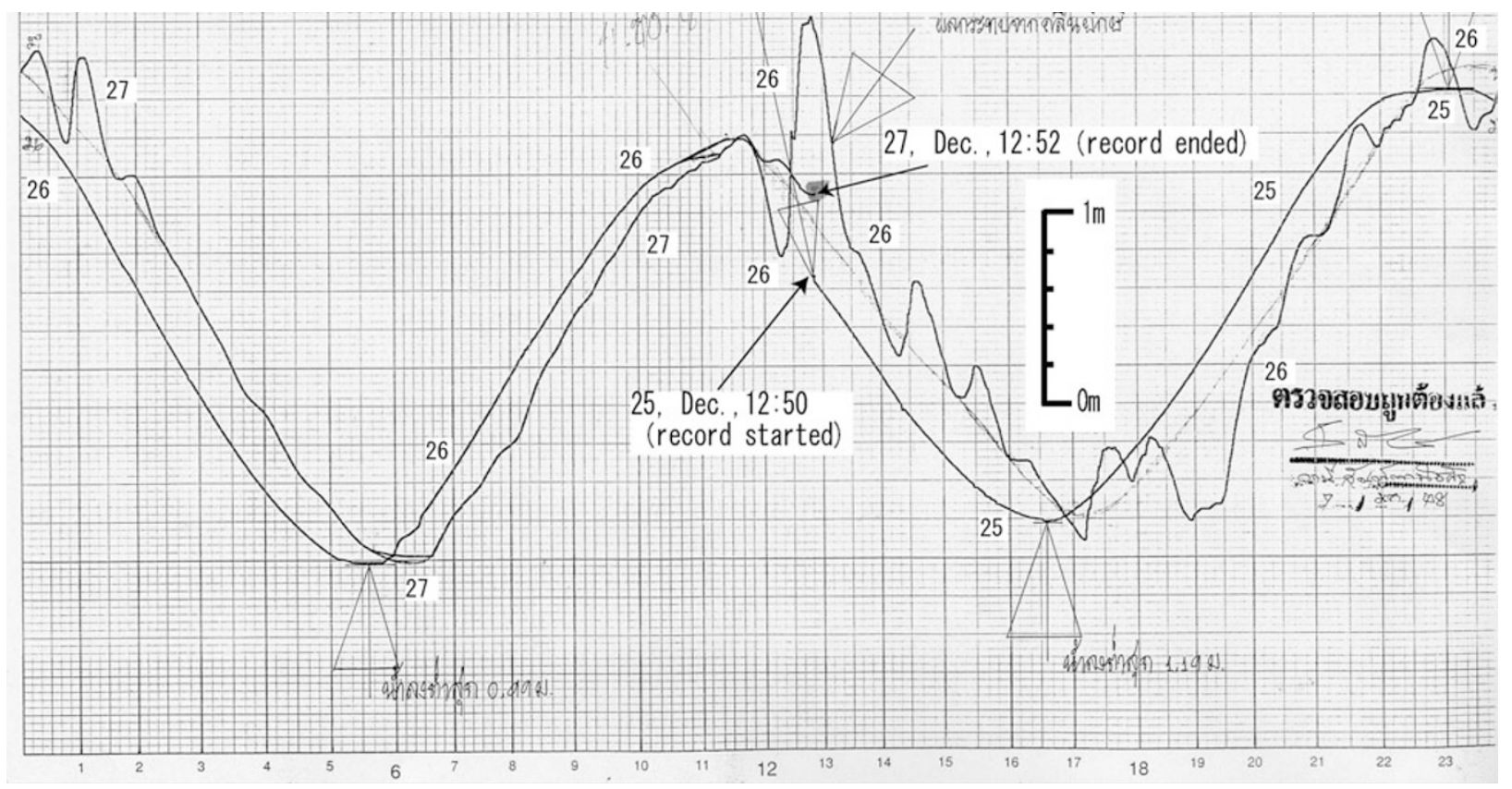

\section{(d) Krabi}

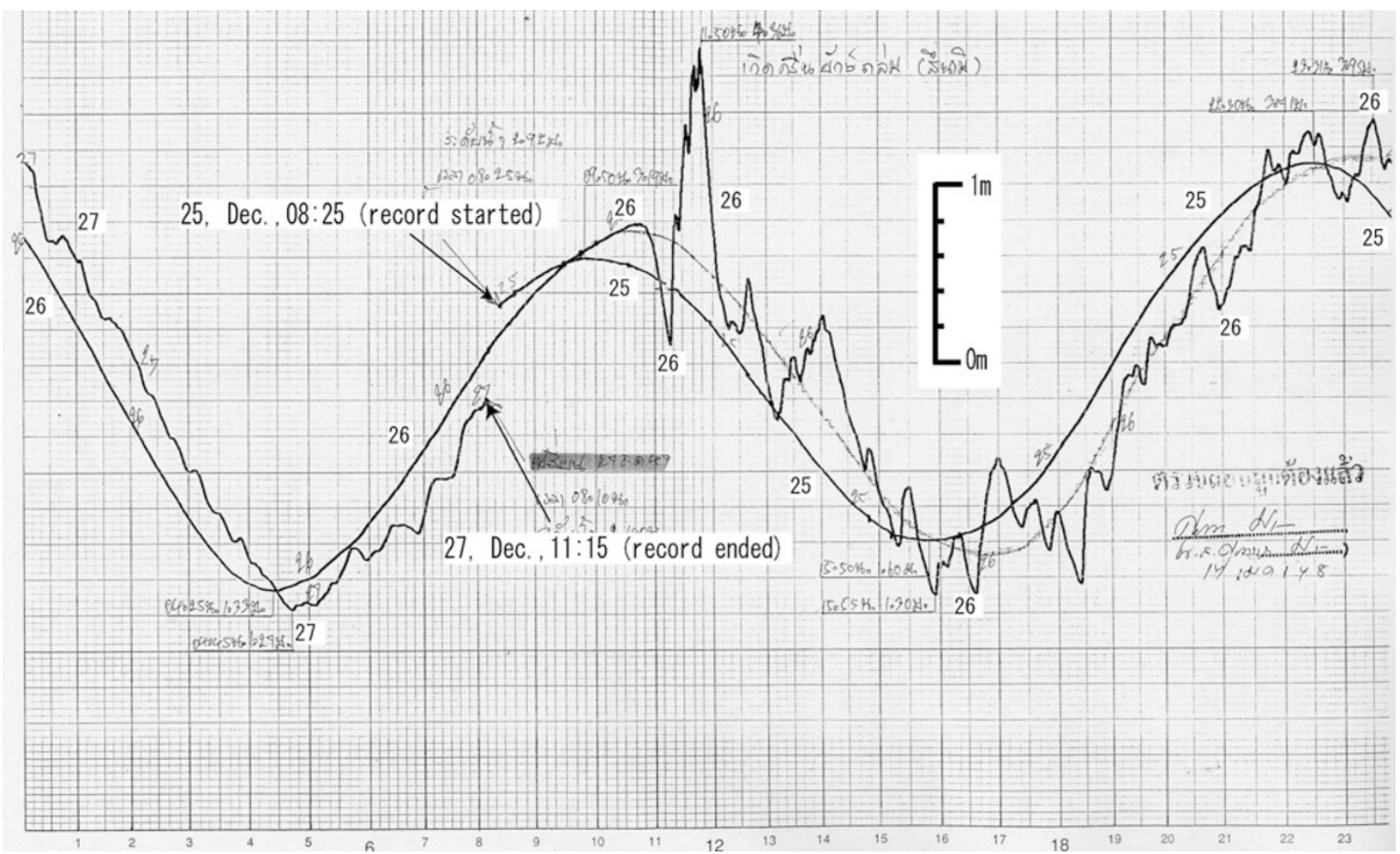

Fig. 3. (continued).

Bernoulli (the Torricelli) theorem cannot be applied. We Kim said the tsunami attacked at about 10:30. It means found a clock broken by the tsunami, which stopped at 10:42 (Photo 5). There still remains a doubt that it was corthe tsunami attacked after about 2 hours and 30 minutes rectly working at that time, while the resident in Ban Nam from the outbreak of the main shock. The main residential area of Ban Nam Kim extends south of these buildings. 


\section{(e) Ranong}

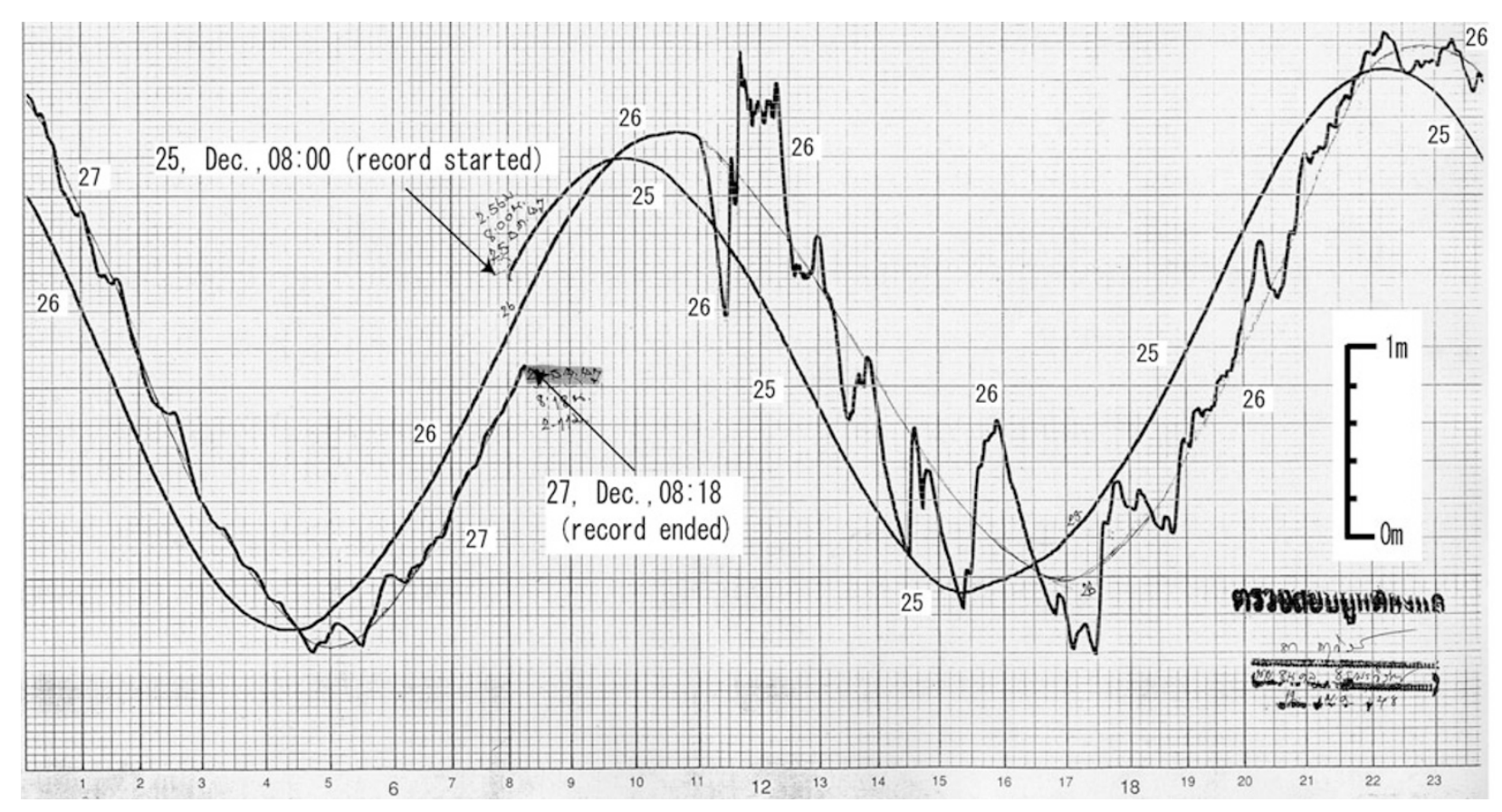

Fig. 3. (continued).

This town suffered from the tsunami most severely in Thailand. Tsunami height of $15.8 \mathrm{~m}$ was measured by the broken branch evidence of a tree, which is located at the south edge of the residential area of this town.

\section{Tide Gauge Records in Thailand}

Eight tide gauge stations exist on the coast of the Andaman Sea, of which five stations; Kuraburi, Tummakarg (Satun), Kan Trang, Krabi, and Ranong are operated by Thai Marine Department, and three stations at Tapanoi, Ban Laen Po and Tarutao are operated by Hydrographic Department of Royal Thai Navy (Fig. 2). Although one of them at Ban Laen Po was not working during the tsunami attacks, seven tide gauge stations recorded the tsunami successfully.

Photo 6 shows a tide gauge station at Ta Phao Noi. A tide station house stands at the top of the tower standing in the sea area about $50 \mathrm{~m}$ from the shoreline and the sea water depth there is about $4 \mathrm{~m}$. The tide gauge well is directly piled on the seabed and an intake hall is at a side of the well. The diameter of the well is $23 \mathrm{~cm}$ shown in Photo 6(a). The float buoy inside the well can move vertically, whose movement can load to the paper through the thread directly. Recorded sheet is rolled on the drum rotating by electricity, which completes one revolution per one day. Tide stations at Ranong and Kuraburi were also investigated as for diameter, water depth, and accuracy of time resolution. Although we visited the tide gauge station at Ban Laen Po, it was not permitted to do measurement because of restricted area of Royal Thai Navy. Properties of tide stations we investigated are shown in Table 2.

In general, two days' waveform by the tide gauge is recorded on each sheet. A tide gauge record shown in (a)

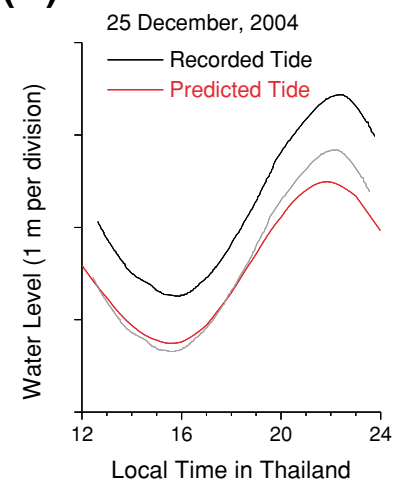

(b)

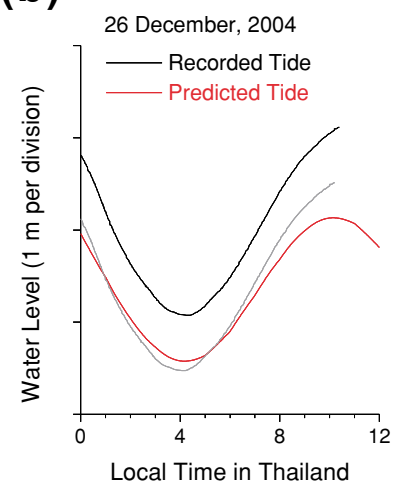

Fig. 4. Comparison of tide gauge records (black lines) with the predicted tides (red lines) at Kuraburi. (a) 12:00 to 24:00 on 25 December 2004, and (b) 0:00 to 12:00 on 26 December 2004. Gray lines shifted from the original tide gauge records are also shown.

Fig. 3(a) was, for example, recorded at Kurabri from 25 through 27 December 2004, including the tsunami on 26 December 2004. It indicates as follows; the first wave withdrew at 10:32 (indicated by A in Fig. 3(a)), followed by the minimum level of $90 \mathrm{~cm}$ at 10:58 (indicated by B), then flooded by $136 \mathrm{~cm}$ in peak-to-peak amplitude tsunami at 11:12 (indicated by C). Maximum peak-to-peak amplitude of $140 \mathrm{~cm}$ recorded at 14:28 (indicated by D). Period of the tsunami at Kuraburi was about $40 \mathrm{~min}$. The other tide gauge data at Tummakarg (Satun), Kan Trang, Krabi, and Ranong are also shown in Figs. 3(b), (c), (d) and (e). These recorded tsunamis indicate that sea level 
initially withdrew with duration in 30 to $60 \mathrm{~min}$, followed by the rising-up. This phenomenon fairly corresponds to the eyewitnesses accounts or the images of the video films obtained along the Andaman Sea. Other two tide gauge records obtained at Ta Phao Noi and Ta Ru Tao are distributed at http://www.navy.mi.th/hydro/tsunami.htm by Hydrographic Department of Royal Thai Navy.

When we visited the tide gauge station at Ta Phao Noi on 26 February, 2005, the time recorded on the sheet had been 11 minutes earlier than the corrected time. Because a sheet is replaced every two days, it is now impossible to evaluate that the time difference existed or not at the time of tsunami attacks. It should be noted that we have to pay attention to the read time of the tsunami arrival is correct or not. The better solution of this problem is considered to compare the tide gauge records to the predicted astronomical tide, and then to compensate based on the times at the flood and the ebb. Accuracy of tsunami arrival time recorded on the sheet at Kuraburi tide gauge station has been estimated. Tide gauge at Kuraburi completely recorded astronomic tide before the tsunami with no disturbances (Fig. 3(a)). Therefore, we compare recorded tide to the predicted tide at 12:00 through 24:00 on 25th and at 0:00 through 12:00 on 26th in order to estimate the time differences. Recorded tide at Kuraburi compares to the predicted tide at Ban Laen Po in Fig. 4. If the recorded tides were shifted 12 minutes earlier than the originals, the recorded tides well coincide with the predicted tides (Fig. 4). This is why the recorded tide might be delayed in 12 minutes at that time. The corrected time related to the tsunami at Kuraburi should be shifted by 12 minutes earlier than the recorded time.

\section{Conclusion}

We carried out tsunami height measurements at totally 37 points along the Andaman Sea mainly on the coast except the coast where Matsutomi et al. (2005) and Satake et al. (2005) had surveyed. Maximum tsunami height was $19.6 \mathrm{~m}$ at Ban Thung Dap, and the second highest tsunami was found to be $15.8 \mathrm{~m}$ at Ban Nam Kim. It is noteworthy that the further northward from this area proceeds, the tsunami heights become lower, in particular, at the coast in Myanmar (Satake et al., 2006). Averaged tsunami heights based on visible water marks around Ban Thale Nok and Ranong are $6 \mathrm{~m}$ and $3 \mathrm{~m}$, respectively. Tsunami height around Ban Nam Kim was the largest, and that of other areas northand southward aside shows gradually lower.

We gathered the records at seven tide gauges on the coast of the Andaman Sea in Thailand working at the 2004 Indian tsunami. Possible time differences between corrected and recorded tides have been found. Comparing the flood and the ebb of the recorded tide at Kuraburi with those of the predicted tide on 25 and 26 December 2004, the time was delayed by 12 minutes. Accuracy of time resolution of the tide gauge data is somewhat unreliable, we should pay attention to read the time of the tsunami arrival for each tide station.

Acknowledgments. Scientists both from Japan and Thailand visited the coast of the Andaman Sea in Thailand to carry out the post tsunami field survey under guidance with the local counterparts. We are grateful to Royol Chitradon and Suwannee Hanmusicwatkun, Hydro and Agro Informatics Institute, Seree Supartid, Rangsit University, Pairash Thajchayapong, Ministry of Science and Technology, Rear Admiral Prayuth Netprada, Hydrographic Department of Royal Thai Navy, and Yasuji Watanabe, National Science and Technology Development Agency for their helpful supports. We also thank to Aekawit Jujenda, the driver of our survey team who helped us many works at the survey field. This paper has been significantly improved through the suggestions and the comments by Yuichiro Tanioka, Kenji Satake, and an anonymous reviewer. This work was supported by Special Coordination Funds for Promoting Science and Technology, by Ministry of Education, Sports, Culture, Science and Technology (MEXT).

\section{References}

Intergovernmental Oceanographic Commission (IOC), Post-tsunami survey field guide, UNESCO IOC Manuals and Guides, No. 37, 62 pp., 1998.

Matsutomi, H., T. Hiraishi, T. Takahashi, F. Matsuyama, K. Harada, S. Nakusakul, S. Supartid, W. Kanbua, C. Siwabowon, S. Phetdee, W. Jachoowong, and M. Srivichai, The December 26, 2004 Sumatra Earthquake Tsunami, Tsunami Field Survey around Phuket, Thailand, http://www.drs.dpri.kyoto-u.ac.jp/sumatra/thailand/phuket_ survey_e.html, 2004.

Namegaya, Y., Y. Tsuji, H. Matsumoto, W. Kanbua, M. Srivichai, V. Meesuk, and S. I. Iwasaki, Field Survey of the Tsunami of the 2004 Indonesia-Sumatra Earthquakes along the coast line of Thailand except Phuket Island and Khao Lack areas, Ann. J. Coast. Eng., JSCE, 2005 (in press, in Japanese).

Satake, K., Y. Okamura, M. Shishikura, and K. Fujima, The December 26, 2004 Sumatra Earthquake Tsunami, Tsunami Field Survey around Phuket, Thailand, http://www.drs.dpri.kyoto-u.ac.jp/sumatra/thailand/ phuket_survey_e.html, 2005.

Satake, K., T. T. Aung, Y. Sawai, Y. Okamura, K. S. Win, W. Swe, C. Swe, T. L. Swe, S. T. Tun, M. M. Soe, T. Z. Oo, and S. H. Zaw, Tsunami heights and damage along the Myanmar coast from the December 2004 Sumatra-Andaman earthquake, Earth Planets Space, $\mathbf{5 8}$ this issue, 243-252, 2006.

Tsuji, Y., Y. Namegaya, and J. Ito, Astronomical tide levels along the coasts of the Indian Ocean, http://www.eri.u-tokyo.ac.jp/namegaya/sumatera/ tide, 2005.

U.S. Geological Survey, Magnitude 9.0-Sumatra-Andaman Islands Earthquake off the west coast of northern Sumatra, http://earthquake. usgs.gov/eqinthenews/2004/usslav, 2005.

Y. Tsuji, Y. Namegaya, H. Matsumoto (e-mail: hmatsumoto@jamstec. go.jp), S. Iwasaki, W. Kanbua, M. Sriwichai, and V. Meesuk 